\title{
Sinh khí hậu và phát triển rừng ngập mặn ven biển tỉnh Thái Bình
}

\author{
Trần Thị Thúy Vân*, Lưu Thế Anh, Hoàng Lưu Thu Thủy, Lê Bá Biên \\ Viện Địa lý, Viện Hàn lâm Khoa học và Công nghệ Việt Nam, 18 Hoàng Quốc Việt, Cầu Giấy, Hà Nội \\ Nhận ngày 03 tháng 01 năm 2017 \\ Chỉnh sửa ngày 12 tháng 03 năm 2017; Chấp nhận đăng ngày 15 tháng 03 năm 2017
}

\begin{abstract}
Tóm tắt: Rừng ngập mặn chiếm diện tích không nhiều ở hai huyện ven biển tỉnh Thái Bình nhưng rất có ý nghĩa về mặt sinh thái và bảo vệ môi trường. Phát triển RNM được đưa ra trên cơ sở nghiên cứu hiện trạng rừng ngập mặn, phân tích điều kiện khí hậu và sinh khí hậu với các ngưỡng sinh thái. Dải ven biển Thái Bình có 14 loài thực vật ngập mặn chủ yếu, liên quan đến các quần xã rừng tự nhiên, quần xã rừng trồng, quần xã thực vật trong đầm nuôi thủy sản và quần xã cỏ tiên phong ở vùng đất mới bồi. Xét trên tổng thể sinh khí hậu khu vực phù hợp phát triển rừng ngập mặn với 14 loài cây này và một số loài nhập trồng từ vùng khác như Nipa fruticans (Dừa nước), Lumnitzera littorea (Cóc đỏ) và Sonneratia apetala (Bần không cánh). Thực vật ngập mặn trong khu vực chịu một số tác động bất lợi của điền kiện sinh khí hậu như: thời kỳ khổ hạn vào đầu mùa đông; thời tiết lạnh trong những đợt gió mùa cực đới hoạt động mạnh; thời tiết nóng trong những tháng mùa hè; bão và áp thấp nhiệt đới.
\end{abstract}

Tù khóa: Sinh khí hậu, thực vật ngập mặn, tỉnh Thái Bình.

\section{Mở đầu}

Rừng ngập mặn $(\mathrm{RNM})$ là một loại rừng đặc biệt có các loài cây gỗ và cây bụi thích nghi với môi trường nước mặn, phát triển ở vùng cửa sông ven biển nhiệt đới và cận nhiệt đới. RNM là một hệ sinh thái hết sức quan trọng, vừa cung cấp nhu cầu về nhiên liệu, thức ăn... cho cộng đồng dân cư ven biển, vừa là bức tường xanh vững chắc chống gió bão, sóng thần, sạt lở, làm sạch môi trường ven biển, hạn chế xâm nhập mặn, bảo vệ nước ngầm, điều hòa khí hậu, duy trì đa dạng sinh học khi có thiên tai và bảo tồn hệ sinh thái ngập nước ven biển...Ở Thái Bình hiện có $3.708,98$ ha diện tích rừng ngập mặn

\footnotetext{
* Tác giả liên hệ. ĐT: 84-915341695.

Email: tranthuyvan_vdl@yahoo.com
}

[1], RNM ven biển nói chung và ở tỉnh Thái Bình nói riêng ngày càng khẳng định vai trò quan trọng trong chiến lược phát triển bền vững của lãnh thổ, đặc biệt trong bối cảnh biến đổi khí hậu và mực nước biển dâng hiện nay.

Thái Bình là một tỉnh thuộc vùng đồng bằng Bắc bộ là nơi tập trung các trung tâm kinh tế, chính trị, xã hội và có tốc độ phát triển thuộc loại trung bình khá của nước ta. Bên cạnh đó, con người với những giá trị tạo dựng của mình đang ngày càng phải đối mặt nhiều hơn với những nguy cơ rủi ro của tự nhiên mà RNM ven biển được xem như một giải pháp phi công trình có lợi ích lớn trong bảo vệ quỹ đất, cân bằng sinh thái và tạo tài nguyên cho phát triển một số loại hình kinh tế có ưu thế về mặt kinh tế sinh thái như thăm quan, du lịch, bảo tồn và phát triển các giá trị sinh học. 
Sự phát triển của RNM, bên cạnh những cơ chế, chính sách của chính quyền, ý thức của người dân thì cũng rất cần những nhận thức về biên sinh thái phát triển của chúng. Vì vậy, bài báo này trình bày một khía cạnh sinh thái môi trường phục vụ phát triển hệ sinh thái RNM ven biển - đó là các đặc thù về sinh khí hậu dải ven biển tỉnh Thái Bình.

\section{Phương pháp nghiên cứu}

- Phương pháp phân tích số liệu thống kê khí hậu: Phân tích khí hậu và sinh khí hậu được dựa trên cơ sở chuỗi số liệu quan trắc tại các trạm khí tượng Thái Bình trong khoảng thời gian 55 năm từ 1960 đến 2015 ;

- Phương pháp khảo sát thực địa: Điều tra hiện trạng rừng ngập mặn nhằm đánh giá khả năng thích nghi của các loài thực vật ngập mặn trong điều kiện sinh khí hậu của khu vực và đánh giá sự sinh trưởng, phát triển của cây chịu ảnh hưởng mạnh bởi các yếu tố: nắng, nhiệt độ không khí, mưa, ẩm, gió,... [2, 3].

- Phương pháp xây dựng biểu đồ sinh khí hậu: Các số liệu thống kê khí hậu nêu trên được sử dụng để xây dựng biểu đồ sinh khí hậu của khu vực [4]. Biểu đồ sinh khí hậu được dựa trên quan hệ giữa lượng mưa $\mathrm{R}(\mathrm{mm})$ - nhiệt độ $\mathrm{T}$ $\left({ }^{\circ} \mathrm{C}\right)$, quan hệ này quyết định tới sự sinh trưởng và phát triển của thực vật:

$-2 \mathrm{~T} \geq \mathrm{R}$ : điều kiện khô hạn

$-2 \mathrm{~T}<\mathrm{R}<100$ : điều kiện đủ ẩm

$-\mathrm{R} \geq 100$ : điều kiện thừa ẩm

Ngoài ra, đối với thực vật ngập mặn, trên biểu đồ sinh khí hậu còn thể hiện các thông số về: nhiệt, mưa và các điều kiện ngưỡng liên quan đến phát triển của thực vật ngập mặn.

\section{Kết quả nghiên cứu}

\subsection{Hiện trạng rù̀ng ngập mặn}

\subsubsection{Hiện trạng rừng ngập mặn}

Tuy chiếm diện tích không lớn song RNM trong khu vực nghiên cứu lại có vai trò đặc biệt trong chuỗi thức ăn, phòng hộ đất liền và đồng thời cũng là nơi có tính nhạy cảm sinh thái cao. Rừng ngập mặn ở Thái Bình, phân bố ở khu vực ven biển thuộc 10 xã, thị trấn của hai huyện Thái Thụy và Tiến Hải. Các quần xã chủ yếu trong rừng ngập mặn: Quần xã Mắm biển (Avicennia marina), Trang (Kandelia obovata) phân bố ngoài cùng, nơi có độ mặn cao và nước ngập sâu. Quần xã Sonneratia caseolaris (Bần chua), Trang (Kandelia obovata), Sú (Aegiceras corniculatum) phân bố ven bờ, nơi có mực nước ngập trung bình. Quần xã Bần chua (Sonneratia caseolaris) chiếm ưu thế, dưới tán là Ô rô (Acanthus ilicifolius), phân bố chủ yếu vùng cửa sông [5].

- Huyện Thái Thụy có hơn 2000ha rừng ngập mặn tập trung tại 5 xã ven biển: Thụy Trường, Thụy Xuân, Thụy Hải, Thái Phượng và Thái Đô. Rừng già ngập mặn ở đây lớn nhất lưu vực sông Hồng với diện tích khoảng 400 ha phân bố ở các xã Thụy Trường và Thụy Xuân. Loài chiếm ưu thế của rừng này là Bần chua (Sonneratia caseolaris). Hầu hết rừng ngập mặn còn lại ở Thái Thụy là rừng trồng loài Kandelia oborata (Trang) xen lẫn Bần chua và Đâng (Rhizophora stylosa) [6]. Nghiên cứu tại khu vực xã Thụy Trường cho thây thực vật ở đây có 111 loài thuộc 38 họ và trong số này có 12 loài cây ngập mặn chính thức và 30 loài tham gia rừng ngập mặn [6].

Huyện Tiền Hải, rừng ngập mặn phân bố chủ yếu ở 5 xã ven biển: Nam Thịnh, Nam Hưng, Nam Phú, Đông Long và Đông Hoàng. Trong đó rừng ngập mặn ở 3 xã Nam Thịnh, Nam Hưng, Nam Phú thuộc Khu bảo tồn thiên nhiên đất ngập nước Tiền Hải có diện tích 1450ha. Đối với khu vực ngoài khu bảo tồn như ở xã Đông Long, hệ thực vật có mức độ đa dạng về thành phần loài cũng thuộc loại khá cao với 66 loài thuộc 33 họ; thực vật ngập mặn ở đây có 8 loài cây ngập mặn chính thức và 19 loài tham gia rừng ngập mặn [7]. Ở Khu bảo tồn thiên nhiên đất ngập nước Tiền Hải, kết quả nghiên cứu của [8] khu vực này có 11 loài cây ngập mặn (1 loài thuộc ngành Dương xỉ và 10 loài ngành Hạt kín); 37 loài cây tham gia rừng ngập mặn (17 loài lớp một lá mầm và 20 loài lớp hai lá mầm của ngành hạt kín). 
Tổng hợp các kết quả nghiên cứu đã công bố kết hợp với điều tra khảo sát thực địa cho thấy, ở dải ven biển tỉnh Thái Bình, thực vật ngập mặn chủ yếu liên quan đến các quần xã rừng tự nhiên, quần xã rừng trồng, quần xã thực vật trong đầm nuôi thủy sản và quần xã cỏ tiên phong ở vùng đất mới bồi.

3.1.2. Các loài thực vật chủ yếu của rừng ngập mặn khu vực ven biển Thái Bình

Thực vật ngập mặn chủ yếu ở khu vực ven biển Thái Bình có 14 loài bao gồm: 1 loài thuộc ngành Dương xỉ; 13 loài thuộc ngành Hạt kín (trong đó có 12 loài thuộc lớp 2 lá mầm, 1 loài thuộc lớp 1 lá mầm). Dưới đây là một số đặc điểm phân bố và sinh cảnh chính của các loài này.

1) Ráng biển (Acrostichum aureum L.) thuộc họ Chân xỉ, ngành Dương xỉ. Loài này có diện phân bố khá rộng, ở các vùng nhiệt đới và á nhiệt đới: khu vực Caribe, nam và đông nam Á, Australasia, đông và nam Phi [9]. Chúng thường thấy ở vùng cửa sông có biên độ triều lớn. Không chỉ ở vùng ngập nước mặn, Ráng biển có thể phát triển trên các môi trường nước lợ đầm lầy ven biển. Ráng biển cũng có thể phát triển dưới tán hoặc ở những nơi trống không có tán rừng rừng ngập mặn trong môi trường. Cây có thể sử dụng làm thuốc sát trùng, tẩy giun sán và cầm máu.

2) Ô rô biển (Acathus ebracteatus Vahl) thuộc họ Ô rô, lớp Hai lá mầm, ngành Hạt kín. Loài này chủ yếu phát triển ở khu vực Đông Nam Á, Nam Trung Quốc, Tây nam Ần Độ và Bắc Úc [9]. Loài này sinh trưởng ở đới giữa cửa sông trong vùng gian triểu cao và giữa [10]. Ở một số nước Đông Nam Á, Ô rô biển được sử dụng trị các bệnh viêm nhiễm, thấp khớp, mụn nhọt, tẩy giun sán, rắn cắn...

3) Ô rô (Acathus ilicifolus L.) thuộc họ Ô rô, lớp Hai lá mầm, ngành Hạt kín. Loài này phát triển từ Nam Ân Độ, Sri Lanka đến Đông Dương, Indonesia, Philippines, bắc Úc, nam Trung Quốc [9]. Đây là loài cây bụi nhỏ mọc dọc theo hồ và đầm lầy và bờ biển. Cây này được sử dụng làm thuốc trị bệnh hen suyễn và bệnh thấp khớp.
4) Sam biển. (Sensuvium portulacastrum $\mathrm{L}$ ) thuộc họ Rau đắng đất, lớp Hai lá mầm, ngành Hạt kín. Loài này phát triển hầu như khắp thế giới, trên đầm lầy mặn, bãi triều nền đá cát kết, đá vôi, sét pha cát. Chiết xuất từ cây này có hoạt tính kháng khuẩn, kháng nấm [11].

5) Mắm biển (Avicennia marina (Forsk) Veirh) thuộc họ Mắm, lớp Hai lá mầm, ngành Hạt kín. Mắm biển có diện phân bố rộng, dọc theo bờ biển phía đông của châu Phi, Tây Nam Á, kéo dài từ Nam và Đông nam châu Á, Nam Trung Quốc đến Hồng Kông, Đài Loan, các đảo ở vùng biển Philippin, biển San hô, Nam Thái Bình Dương, Úc và New Zealand [9]. Mắm biển sinh trưởng tốt ở vùng có lượng mưa trung bình hàng năm tương đối cao, nhiệt độ trung bình năm $17-26^{\circ} \mathrm{C}, \mathrm{pH} 6-8$, tuy nhiên nó cũng là một trong số ít loài ngập mặn chịu được môi trường khô cằn ven biển như ở Tây Nam Á và Đông Phi. Loài này thường thấy ở cửa sông đoạn chuyển tiếp và đoạn sát biển, ở khu vực gian triều [10]. Mắm biển thường là cây tiên phong ở vùng đất ngập nước, phát triển trên bùn có tỷ lệ cát cao, dường như không phát triển trên bùn thuần nhất [12]. Gỗ cây Mắm biển có thể dùng làm củi hoặc đóng đồ gia dụng. Quả ăn được, hoa làm thức ăn cho ong mật. Một số bộ phận của cây được dùng làm thuốc.

6) Cóc vàng (Lumnitzera racemosa (Gaud.) Presl.), thuộc họ Bàng, lớp Hai lá mầm, ngành Hạt kín. Cóc vàng có diện phân bố tương đối rộng: khu vực Đông Phi, Nam Á, Đông Nam Á, Nam Trung Quốc và Bắc Úc [9]. Cóc vàng thường thấy ở đoạn cửa sông xa biển ở các bãi triều giữa và bãi triều cao [10]. Nó là loài tiên phong, sinh trưởng tương đối nhanh, chịu được độ mặn trung bình 15 - 30\%o [13]. Cóc vàng được dùng làm củi đốt, cột nhà, hàng rào ở Philippin, vỏ dùng trong thuộc da.

7) Cóc kèn (Derris trifoliata (Benth) Barker), thuộc họ Đậu, lớp Hai lá mầm, ngành Hạt kín. Cóc kèn phân bố chủ yếu ở khu vực từ đông Phi tới vùng nhiệt đới và á nhiệt đới của châu Á và Úc [9]. Chúng phát triển dọc theo các sông có kênh rạch ở các nơi có nước mặn. Cây có vị mặn chát, có tác dụng tiêu đờm, kháng sinh sát trùng. Lá có tác dụng cầm máu, 
lợi tiểu. Rễ có độc, dùng làm thuốc giảm đau, sát trùng.

8) Giá (Excoecaria agallaocha $\mathrm{L}$ ), thuộc họ Thầu dầu, lớp Hai lá mầm, ngành Hạt kín. Đây là loài phân bố ven biển từ Nam Á, qua Đông Nam Á tới Nam Trung Quốc và Bắc Úc [9]. Cây có thể rụng lá ở khu vực lạnh/khô. Giá có thể sử dụng làm đồ gỗ, trang trí, thuốc giảm đau.

9) Sú (Aegiceras corniculatum (L.) Blanco), thuộc họ Đơn nem, lớp Hai lá mầm, ngành Hạt kín. Cây này phân bố từ Ấn Độ qua Đông Nam Á đến Hoa Nam, New Guinea và Úc [9]. Đây là cây loài cây bụi hoặc cây gỗ nhỏ phát triển ven sông, lạch có nền đất bùn cát. Loài cây này mọc thành cụm, sống khỏe, có thể chịu được lạnh. Vỏ của loài này có thể sử dụng làm thuốc nhuộm, làm thuốc, lá có thể ăn được.

10) Vẹt dù (Bruguiera gymnorrohiza (L)), thuộc họ Đước, lớp Hai lá mầm, ngành Hạt kín. Loài cây này có diện phân bố tương đối rộng, ở vùng nhiệt đới, á nhiệt đới : nam và bắc châu Phi, Madagascar, Seychelles, Sri Lanka, Đông nam Á, Ryukyu, Australia, Polynesia [9]. Nó thường thấy ở đoạn cửa sông chuyển tiếp và cửa sông giáp biển, trên bãi triều giữa và bãi triều cao [10]. Vẹt dù sinh trưởng tốt ở vùng có lượng mưa trung bình năm tương đối cao, nhiệt độ trung bình năm $20-26^{\circ} \mathrm{C}, \mathrm{pH}$ từ $6,0-8,5$. Cây có thế dùng làm củi đốt.

11) Trang (Kandelia obovata Sheue Liu \& Yong), thuộc họ Đước, lớp Hai lá mầm, ngành Hạt kín. Loài này phân bố tương đối hạn chế ở miền Bắc và miền Nam Việt Nam, Nam Trung Quốc, Đài Loan, Nam Nhật Bản (tới vĩ độ $35^{\circ}$ Bắc) và đảo Natuna (Indonesia) [9]. Chúng thường thấy ở đoạn cửa sông giáp biển trên các bãi triều thấp [10]. Cây mọc trên đất bùn cát dọc sông có độ mặn thay đổi, thường mọc hỗn giao với Đước, Bần, Sú. Cây Trang có tính thích nghi tốt với sự thay đổi độ mặn. Cây có thể dùng làm củi đốt.

12) Đâng (Rhizophora stylosa Griff.) thuộc họ Đước, lớp Hai lá mầm, ngành Hạt kín. Loài này phân bố ở khu vưc Nam Á, bao gồm Ấn Độ (các đảo Andaman, Nicobar và bang Orissa),
Trung Quốc (từ đảo Hải Nam đến Đài Loan), Indonesia (chưa thấy ở Kalimantan), Nhật Bản, Philippin Singapor, Bắc Việt Nam, Cam Pu Chia, Myanmar, Malaysia, Bangladesh và Thái Lan [9]. Ở châu Đại dương, nó có mặt ở khu vực Tây Băc, Đông Bắc, Đông Nam Úc, Micronesia, Northern Marianas, Marshall, Fiji, Guam, New Caledonia, Papua New Guinea, Solomon Islands, Tonga, Tuvalu, Kirabati, Nauru và Vanuatu. Đâng thường thấy ở các cửa sông vùng biển mở. Đây là loài ưa khí hậu nóng ẩm, có cường độ chiếu sáng mạnh, có lượng mưa hàng năm cao từ $1.500-2.500 \mathrm{~mm}$. Độ mặn biến động từ $5-60 \%$, nhưng thích hợp nhất vào khoảng 25-30\%o. Độ ngập triều trung bình từ 100-300 ngày/năm thích hợp cho sự sinh trưởng của Đâng, độ ngập triều thấp như: bãi bồi ven biển, vùng trũng nội địa... thời gian ngập trên 300 ngày/năm và độ ngập triều cao dưới 100 ngày/năm không thích hợp cho sự sinh trưởng của cây. Gỗ Đâng thường được dùng làm củi, làm các dụng cụ sản xuất muối; chủ yếu trồng làm cây chắn sóng, bảo vệ đê do có hệ rễ chống phát triển. Có thể khai thác tanin để nhuộm lưới.

13) Bần chua (Sonneratia caseolaris (L.) Engl.), thuộc họ Bần, lớp Hai lá mầm, ngành Hạt kín. Bần chua phân bố phân bố ở vùng rừng ngập mặn nhiệt đới và á nhiệt đới : Bangladesh, Brunei Darussalam, Cambodia, Trung Quốc (đảo Hainan), Ân Độ, Indonesia, Malaysia, Myanmar, Philippines, Singapore, Sri Lanka, Thailand, Viet Nam, bắc Australia, Papua New Guinea, quần đảo Solomon, Vanuatu, New Caledonia và Maldives [9]. Nó phát triển ở vùng có lượng mưa hàng năm tương đối cao, nhiệt độ trung bình từ $20-27^{\circ} \mathrm{C}, \mathrm{pH}$ từ $6,0-$ 6,5 . Bần chua sống chủ yếu ở đoạn cửa sông xa biển trong vùng bãi triều thấp [10]. Đây cũng là loài tiên phong ở các bãi triều mới hình thành [14]. Bần chua có thể sử dụng với nhiều mục đích khác nhau: quả có thể dùng làm đồ ăn, thức uống, rễ thở của cây dùng làm nút chai, các chất tannin trong vỏ dùng làm thuốc nhuộm, lá làm thức ăn gia súc.

14) Cỏ gấu biển (Cyperus stoloniferus Retz), thuộc họ Cói, lớp Một lá mầm, ngành 
Hạt kín. Cỏ gấu biển có diện phân bố rộng : Trung Quốc, Mauritius, Papua New Guinea, quần đảo Solomon, Madagascar, Malaysia, Australia, Đài Loan, Indonesia, Maldives, Việt Nam, Thái Lan, Pakistan, Ân Độ [9]. Nó phát triển ở khu vực ẩm ướt, trên đất cát hoặc cát biển. Cỏ gấu biển có thể sử dụng làm thuốc chữa bệnh, lợi tiểu, trợ tim.

\subsection{Sinh khi hậu với phát triển thực vật ngập mạn khu vưc ven biển Thái Bình}

\subsubsection{Sinh khí hậu khu vực ven biển Thái} Bình

Khí hậu ở khu vực thuộc khí hậu nhiệt đới gió mùa có mùa đông lạnh, do ảnh hưởng của front cực đới khiến cho biên độ nhiệt năm đạt tới $12-13{ }^{\circ} \mathrm{C}$. Nhiệt độ trung bình năm khoảng $23,4^{\circ} \mathrm{C}$, nhiệt độ trung bình tháng dao động trong khoảng $16-29^{\circ} \mathrm{C}$ với cực tiểu là tháng $\mathrm{I}$ và cực đại vào tháng VII. Tổng số giờ nắng đạt 1500-1600 giờ/năm; nắng nhiều trong thời gian từ tháng $\mathrm{V}$ đến tháng $\mathrm{X}$ với thời lượng trên 160 giờ/tháng, cao nhất là tháng $\mathrm{V}$ và tháng $\mathrm{VII}$; tháng ít nắng nhất là tháng II và III với thời lượng dưới 50 giờ/tháng. Lượng mưa trong khu vực đạt 1600-1700 mm/năm. Biến trình mưa có một cực đại vào tháng VIII, IX, muộn hơn so với khu vực 1 , và một cực tiểu vào tháng XII. Ba tháng mùa đông (XII, I và II) là thời kỳ khô nhất với lượng mưa không quá $30 \mathrm{~mm} /$ tháng. Đáng chú ý vào nửa cuối tháng mùa đông thường có hiện tượng thời tiết nồm và mưa phùn. Do đặc điểm biển mở và độ cao địa hình thấp nên khu vực có nguy cơ bị tác động rất mạnh của gió, bão. Tốc độ gió trung bình đạt 2$3 \mathrm{~m} / \mathrm{s}$. Mùa hạ trong khu vực cũng được gió biển làm dịu bớt nắng nóng và tăng thêm nguồn ẩm, không khắc nghiệt như đồng bằng Trung bộ. Tốc độ gió cực đại có giá trị cao (trên 40 $\mathrm{m} / \mathrm{s}$ ) trong thời gian từ tháng VII đến $X$, lớn nhất có thể đạt $48 \mathrm{~m} / \mathrm{s}$. Trong thời kỳ gió mùa Đông Bắc thịnh hành, tốc độ gió cực đại không quá $20 \mathrm{~m} / \mathrm{s}$.

Ảnh hưởng của khí hậu đến sinh trưởng của thực vật trước hết thể hiện qua mối quan hệ giữa biến trình mưa $\mathrm{R}(\mathrm{mm})$ và biến trình nhiệt độ $\mathrm{T}\left({ }^{\circ} \mathrm{C}\right)$ trong năm. Ngoài ra, các điều kiện khác như nhiệt độ, lượng mưa, gió, bão, dông, mưa đá, sương mù, sương muối,. . . cũng có vai trò quan trọng đối với sự sinh trưởng và phát triển của thực vật ngập mặn. Về nhiệt độ, theo thống kê cho thấy RNM trên thế giới thường phân bố ở những khu vực có nhiệt độ trung bình tháng lạnh nhất lớn hơn $20^{\circ} \mathrm{C}$ và biên độ nhiệt theo mùa không vượt quá $10^{\circ} \mathrm{C}$ [15]. Tuy nhiên rừng ngập mặn có thể phát triển đến giới hạn đường nhiệt độ không khí tháng lạnh nhất là $16^{\circ} \mathrm{C}$ [16]. Nhiệt độ khoảng $5^{\circ} \mathrm{C}$ và sương muối cũng làm hạn chế sự phân bố của RNM $[15,16]$. Nhiệt độ thích hợp cho hoạt động sinh lý của lá các cây thực vật ngập mặn là $25-28^{\circ} \mathrm{C}$ [17] và các hoạt động này giảm đi rõ rệt khi nhiệt tăng vượt quá $35^{\circ} \mathrm{C}[18,19]$. Theo tài liệu của Phan Nguyên Hồng [20], trong ngày $18 / \mathrm{IV} / 1990$, nhiệt độ lên tới $40^{\circ} \mathrm{C}$ trong không khí và $42^{\circ} \mathrm{C}$ trong đất đã làm cho các hoạt động sinh lý như thoát hơi nước, quang hợp của cây Đước (Rhizophora apiculata) ngừng hoạt động. Tương tự như vậy, Milan [21] phát hiện thấy một loạt cây Mắm (Avicennia) bị chết trong vòng 48 giờ khi chịu nhiệt độ $39-40^{\circ} \mathrm{C}$. Nhiều công trình nghiên cứu nước ngoài cho thấy rằng đối với quá trình quang hợp, nhiệt độ tối ưu là trong khoảng $28-32^{\circ} \mathrm{C}$ và đến nhiệt độ $38-40^{\circ} \mathrm{C}$ thì quá trình này hầu như không còn hoạt động [22].

Lượng mưa có ảnh hưởng đến sự sinh trưởng, sổ lượng loài và kích cỡ cây ngập mặn. Ở vùng nhiệt đới như Thái Lan, Australia, Việt Nam, rừng ngập mặn phát triển mạnh ở những nơi có lượng mưa trong năm cao (1800$2500 \mathrm{~mm}$ ); vùng ít mưa số lượng loài và kích thước cây giảm [13]. Gió có tác dụng trực tiếp hoặc gián tiếp đến sự hình thành của rừng ngập mặn theo nhiều cách. Gió làm tăng cường độ thoát hơi nước, giúp cho việc phát tán hạt và cây giống, làm thay đổi lực dòng triều và dòng chảy ven bờ, vận chuyển phù sa, trầm tích, tạo nên những bãi bồi mới, là nơi cho những loài cây tiên phong của rừng ngập mặn phát triển. Gió mùa làm tăng lượng mưa, đem không khí lạnh (gió mùa Đông Bắc) hoặc không khí khô nóng (gió phơn Tây Nam) ảnh hưởng rất lớn đến sự sinh trưởng và phân bố của thực vật 
nhiệt đới nói chung và cây ngập mặn nói riêng. Gió mạnh gây sóng lớn đặc biệt là khi có bão tác dụng hủy hoại trực tiếp cây cối cũng như các công trình ven bờ.

Đối với dải ven biển biểu đồ sinh khí hậu được xây dựng theo số liệu của trạm khí tượng Thái Bình và các yêu cầu sinh trưởng của thực vật ngập mặn về mặt khí hậu (Hình 1). Khu vực ven biển Thái Bình được đặc trưng bởi khí hậu nhiệt đới gió mùa có mùa đông lạnh, mưa hè. Biểu đồ sinh khí hậu cho thấy, khu vực có thời kỳ khô hạn kéo dài tới 3 tháng, từ tháng XII đến tháng $\mathrm{II}$, đường cong nhiệt độ $(2 \mathrm{~T})$ cao hơn đường cong mưa $(\mathrm{R})$, đây là thời kỳ hạ chế khả năng sinh trưởng và phát triển của cây. Các thời kì còn lại, tử tháng III đến tháng XI, là đủ ẩm hoặc thừa ẩm đối với sự phát triển của cây. Trong đó, từ tháng $\mathrm{V}$ đến tháng $\mathrm{X}$ là thời kỳ thừa ẩm đối với cây trồng $(\mathrm{R} \geq 100 \mathrm{~mm})$.

Xét về mặt nhiệt độ, khu vực có nhiệt độ trung bình năm là $23,3^{\circ} \mathrm{C}$, tương đối thích hợp đối với hoạt động sinh lý của cây. Biên độ nhiệt theo mùa $13^{\circ} \mathrm{C}$ với 3 tháng, cũng là 3 tháng mùa khô, từ tháng XII đến tháng II, có nhiệt độ trung bình tháng dưới $20^{\circ} \mathrm{C}$, là những yếu tố không thích hợp cho sinh trưởng và phát triển cây ngập mặn. Đặc biệt là khu vực này có 1 tháng nhiệt độ tối thấp trung bình tháng dưới $15^{\circ} \mathrm{C}$ (tháng $\mathrm{I}$ ) và 2 tháng (tháng $\mathrm{XII}$ và $\mathrm{I}$ ) có nhiệt độ tối thấp dưới $5^{\circ} \mathrm{C}$, có ảnh hưởng lớn đến sự phát triển của cây, tuy nhiên nhiệt độ tối thấp tuyệt đối không xuống dưới $4^{\circ} \mathrm{C}$ nên ảnh hưởng lạnh do nhiệt độ thấp đối với thực vật ở đây là không lớn. Các tháng $\mathrm{V}$ và tháng $\mathrm{IX}$, có nhiệt độ trung bình tháng khoảng $27^{\circ} \mathrm{C}$, nằm trong khoảng nhiệt độ $25-28^{\circ} \mathrm{C}$, khoảng thích hợp cho các hoạt động sinh lý của các lá cây thực vật ngập mặn. Về ngưỡng nhiệt độ cao, đáng lưu ý là khu vực có tới 5 tháng có khả năng xuất hiện nhiệt độ tối cao trên $35^{\circ} \mathrm{C}$, từ tháng $\mathrm{V}$ đến tháng IX, có nhiều tháng nhiệt độ tối cao trên $38^{\circ} \mathrm{C}$, ngưỡng mà quá trình quang hợp gần như ngừng hoạt động, và cực đại có thể lên tới trên $39^{\circ} \mathrm{C}$.

Lượng mưa trung bình khu vực khoảng $1700 \mathrm{~mm} /$ năm hơi thấp hơn so với ngưỡng phát triển thích hợp (>1800 mm), thời kỳ khô đối với

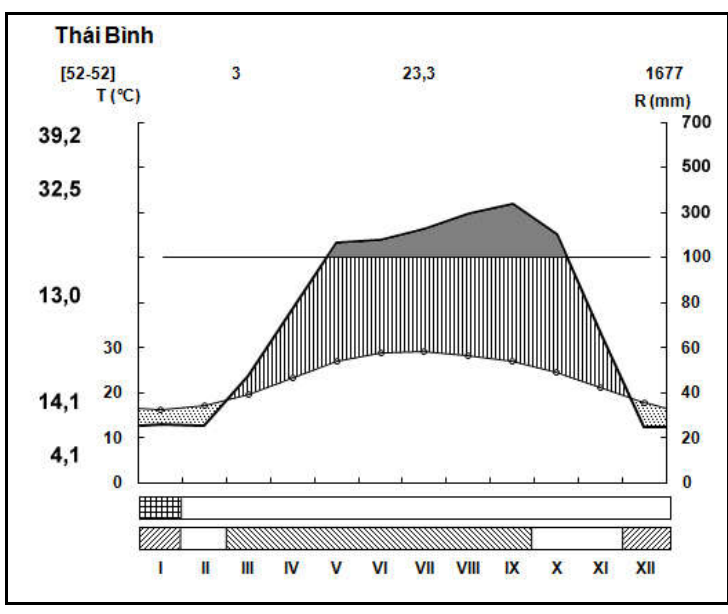

Hình 1. Biểu đồ sinh khí hậu trạm Thái Bình.

chu kỳ sinh trưởng của cây kéo dài 3 tháng (XII, I, II) nhưng lượng thiếu ẩm không lớn do vậy điều kiện mưa, ẩm trong khu vực chỉ mang tính chất giảm bớt khả năng sinh trưởng và phát triển của cây.

Do không có đảo che chắn phía ngoài, hàng năm khu vực chịu tác động của bão, áp thấp nhiệt đới vào mùa mưa, gió mùa đông bắc lạnh vào mùa khô nên không thuận lợi cho một số loài ngập mặn đến định cư [13]. Gió mùa đông Đông Bắc thịnh hành từ tháng XI đến tháng IV mang không khí lạnh, khô, ít mưa. Bão và áp thấp nhiệt đới thường đổ bộ vào Thái Bình và phụ cận thường xuất hiện trong khoảng thời gian từ tháng $\mathrm{V}$ đến tháng $\mathrm{X}$, nhiều nhất là trong khoảng tháng VII đến tháng IX, hàng năm. Bão thường có gió từ cấp 8 đến cấp 12 . Trung bình mỗi năm Thái Bình chịu ảnh hưởng từ 3 đến 5 cơn bão hoặc áp thấp, trong đó có từ 1 đến 2 cơn bão hoặc áp thấp đổ bộ trực tiếp không những làm phá hủy rừng ngập mặn mà còn gây thiệt hại về người và kinh tế. Những năm gần đây bão có xu hướng gia tăng về cường độ và số lượng cơn bão làm gia tăng các tác động phá hủy này.

3.2.2. Sinh khí hậu với phát triển thực vật ngập mặn khu vực ven biển Thái Bình

Khu vực ven biển Thái Bình có 14 loài thực vật ngập mặn chủ yếu. Cả 14 loài này đều có diện phân bố rộng ở quy mô thế giới, châu lục hoặc khu vực Đông Nam Á. 
- Các loài có diện phân bố rộng ở quy mô thế giới bao gồm : Ráng biển, Sam biển, Mắm biển, Cóc vàng, Cóc kèn, Vẹt dù. Diện phân bố của chúng bao gồm : Đông Phi, Nam Á, Đông Nam Á, Bắc Châu Đại dương. Ngoài ra, Ráng biển còn thấy có mặt ở vùng Caribe và Tây Phi. Mắm biển cũng đã ghi nhận có mặt ở Tây Nam Á, nơi có điều kiện khí hậu khô, khắc nghiệt.

- Các loài có quy mô phân bố hẹp hơn, giới hạn trong khuôn khổ Đông Nam Á và mở rộng sang Nam Á, Nam của Đông Á, Bắc châu Đại dương bao gồm: Ô rô biển, Ô rô, Giá, Sú, Trang, Đâng, Bần chua và Cỏ gấu biển. Tuy nhiên, Trang có diện phân bố tương đối hẹp, hạn chế ở miền Bắc và miền Nam Việt Nam, đảo Natuna của Indonesia, miền Nam Trung Quốc (bao gồm cả đảo Hải Nam), Đài Loan và Nam Nhật Bản. Như vậy loài này có khả năng chịu lạnh tốt.

Nhìn chung cả 14 loài thực vật ngập mặn chủ yếu ở Thái Bình đều là những loài có diện phân bố rộng bao trùm lên cả khu vực nghiên cứu nên chúng đều có khả năng phát triển tốt ở đây. Trên thực tế sự tồn tại của các quần xã tự nhiên hay rừng trồng với các cây Bần, Trang, Ổ rô, Sú, Đâng, . . đã cho thấy rằng các cây này rất phù hợp với điều sinh khí hậu của khu vực. Hay nói cách khác, đây là những loại cây có thể sử dụng để phát triển rừng ngập mặn trong ở ven biển Thái Bình.

Ở các khu vực ven biển huyện Giao Thủy tỉnh Nam Định, nơi có điều kiện sinh khí hậu tương tự như Thái Bình, một số loài cây từ nơi khác đã được đem trồng như : Dừa nước (Nipa fruticans) và Cóc đỏ (Lumnitzera littorea) đem từ Cần Giờ, Bần không cánh (Sonneratia apetala) đem từ Myanmar [23, 24].

Dừa nước (Nipa fruticans) thuộc họ Dừa. Trên thế giới có diện phân bố từ Sri Lanka và châu thổ sồng Hằng qua Tây Thái Bình Dương. Ở Nam và Đông Nam Á, nó có mặt ở Sri Lanka (là nơi được có diện tích được mở rộng do trồng trọt), Ân Độ, Bangladesh, Myanmar, Thái Lan, Malaysia, Singapore, Indonesia, Brunei Darussalam, Cambodia, Việt Nam, Trung Quốc (đảo Hải Nam), Nhật Bản (giới hạn phía Bắc của loài là đảo Iriomote). Ở Châu đại dương, loài này có ở Bắc Úc, Micronesia, Guam, Palau, Papua New Guinea, quần đảo Solomon [9]. Ở Việt Nam Dừa nước hiện nay phân bố chủ yếu ở các tỉnh Nam Bộ và Nam Trung Bộ; Dừa nước tự nhiên hiện không có ở các tỉnh miền Bắc. Dừa nước thường mọc ở đoạn cửa sông xa biển, trên các bãi triều [10]. Giới hạn Bắc của loài là đảo Iriomote (Nhật Bản), nơi có nhiệt độ trung bình năm $23,6^{\circ} \mathrm{C}$, nhiệt độ trung bình các tháng dao động trong khoảng từ $18,3^{\circ} \mathrm{C}$ (tháng I) đển $28,9^{\circ} \mathrm{C}$ (tháng VII), lượng mưa 2309 $\mathrm{mm} / \mathrm{năm}$, chịu tác động của bão, so với sinh khí hậu Thái Bình thì tính chất sinh khí hậu khá tương đồng, ngọai trừ lượng mưa có cao hơn. Thử nghiệm đem Dừa nước từ Bến Tre về tại Quảng Ninh từ năm 1996 đến năm 2007 cho thấy loài này có thể phát triển song khả năng sinh trưởng có kém hơn với nơi nó được đem đi [25]. Như vậy, có thể thấy Dừa nước có thể phát triển được ở khu vực ven biển Thái Bình.

Cóc đỏ (Lumnitzera littorea) thuộc họ Bàng, phân bố ở Nam Á bao gồm Brunei Darussalam, Indonesia, India, Malaysia, Singapore, Thailand, Viet Nam, Trung Quốc (đảo Hải Nam), Đài Loan. Nó cũng phân bố rộng rãi ở các đảo trên Thái Bình Dương như: Papua New Guinea, quần đảo Solomon, New Caledonia, and Micronesia [9]. Ở Việt Nam, Cóc đỏ phân bố ở Cần Giờ, đảo Phú Quốc, và Côn Đảo [9] loài này còn có ở Thừa Thiên Huế (đầm Phá Tam Giang), Khánh Hoà (Cam Ranh), Bạc Liêu. Cóc đỏ thường sống thành cụm, mọc ở rừng ngập mặn ven biển, cửa sông, ven các đảo. Loài này có thể sử dụng làm chất đốt hoặc đồ gỗ thông thường. Ở miền Bắc Việt Nam, Cóc đỏ mới được đem trồng thử nghiệm ở Giao Thủy (Nam Định), rất gần với Thái Bình. Tuy nhiên sự có mặt của loài này ở Đài Loan [9], nơi mà thực vật ngập mặn đang phát triển trong điều kiện khí hậu nhiệt đới và á nhiệt đới, nhiệt độ trung bình năm $22-25^{\circ} \mathrm{C}$, lượng mưa $2500 \mathrm{~mm} /$ năm, chịu tác động của bão chủ yếu từ tháng $\mathrm{V}$ đến tháng $\mathrm{X}$ [26], điều kiện $\sinh$ khí hậu tương đối gần gũi với ở Thái Bình, ngoại trừ yếu tố mưa, cho thấy Cóc đỏ cũng có khả năng phát triển được ở ven biển Thái Bình. 
Bần không cánh (Sonneratia apetala) thuộc họ Bần chỉ phân bố ở khu vực Nam Á : Bangladesh, Myanmar, and India, bao gồm các cả các đảo Andaman và Nicobar [9]. Loài này thường mọc ở đoạn cửa sông xa biển, trên các bãi triều thấp và bãi triều giữa [10], đây là loài tiên phong ở các bãi triều mới hình thành [14]. Bần không cánh có thể sử dụng trong xây dựng hoặc làm củi, quả ăn được. Bần không cánh đã được đem trồng ở Quảng Đông và Phúc Kiến của Trung Quốc [9]. Bần không cánh phát triển tốt tại Trung Quốc kể từ khi được đem trồng năm 1985 đến nay và loài này chịu được lạnh, có thể duy trì sinh trưởng bình thường ở nơi có nhiệt độ trung bình tháng lạnh nhất là $14,1^{\circ} \mathrm{C}$, và nhiệt độ tối thấp là $0,2^{\circ} \mathrm{C}[27]$. Cây này cũng đã được mang từ Myanmar về trồng thử nghiệm tại Giao Thủy (Nam Định). Như vậy, Bần không cánh có thể trồng được ở ven biển Thái Bình.

Nhìn chung, về mặt sinh khí hậu, rừng ngập mặn ở khu vực ven biển Thái Bình có thể phát triển tốt. 14 loài thực vật ngập mặn chủ yểu ở Thái Bình đều thích nghi được với điều kiện khu vực. Nhiều cây trong số này có thể sử dụng làm thuốc chữa bệnh, thực phẩm, chất đốt, xây dựng. Song quan trọng hơn cả là các loài cây này là thành phần chính tạo nên hệ sinh thái rừng ngập mặn, bảo tồn đa dạng sinh học, chống xói lở, bảo vệ đê biển, che chắn cho dân cư ven biển trước sự tấn công của bão. Chính vì vậy, đã từ lâu đời, ông cha ta đã biết trồng rừng ngập mặn để khai hoang lấn biển mở rộng diện tích môi trường sinh sống và sản xuất ở vùng ven biển Thái Bình nói riêng cũng như toàn vùng đồng bằng sông Hồng nói chung.

Một số loài như Dừa nước (Nipa fruticans), Cóc đỏ (Lumnitzera littorea) và Bần không cánh (Sonneratia apetala) được nhập trồng ở khu vực lân cận cũng có thể phát triển được ở Thái Bình. Các loài khác nếu đem trồng tại đây thì cần có những đánh giá đối sánh điều kiện sinh khí hậu khu vực ở đó, với khu vực Thái Bình để có được những quyết định hợp lý.

Ở Thái Bình một số điều kiện sinh khí hậu chính làm hạn chế khả năng sinh trưởng và phát triển của cây, ảnh hưởng đến sự phát triển rừng ngập mặn là:
- Từ tháng XII đến tháng II là thời kỳ khô hạn, đây cũng là thời kỳ mùa đông lạnh với nhiệt độ thấp

- Tháng I có nhiệt độ tối thấp trung bình tháng dưới $15^{\circ} \mathrm{C}$

- Tháng XII và tháng I là các tháng có nhiệt độ tối thấp tuyệt đối dưới $5^{\circ} \mathrm{C}$

- Từ tháng $\mathrm{V}$ đến tháng IX là các tháng có nhiệt độ tối cao tuyệt đối trên $35^{\circ} \mathrm{C}$

- Từ tháng $\mathrm{V}$ đến tháng $\mathrm{X}$, đặc biệt từ tháng VII đến tháng IX, thường có tác động của bão và áp thấp nhiệt đới.

Đây là những bất lợi sinh khí hậu chính cần lưu tâm để có các kế hoạch trồng rừng và chăm sóc cây hợp lý.

\section{Kết luận}

Thực vật ngập mặn ở dải ven biển Thái Bình chủ yếu liên quan đến các quần xã rừng tự nhiên, quần xã rừng trồng, quần xã thực vật trong đầm nuôi thủy sản và quần xã cỏ tiên phong ở vùng đất mới bồi. Thực vật ngập mặn chủ yếu ở đây có 14 loài bao gồm: 1 loài thuộc ngành dương xỉ; 13 loài thuộc ngành Hạt kín (12 loài lớp 2 lá mầm, 1 loài thuộc lớp 1 lá mầm).

Xét trên tổng thể khu vực ven biển Thái Bình có chế độ nhiệt, chế độ mưa ẩm, về cơ bản, cho phép phát triển rừng ngập mặn ở đây. Biên độ nhiệt năm tương đối cao, lượng mưa hơi thấp có thể làm hạn chế về số lượng, thành phần loài, kích thước cây ngập mặn trong khu vực so với các nơi khác.

Với điều kiện sinh khí hậu hiện tại, các loài thực vật ngập mặn chủ yếu của Thái Bình và một số loài được nhập trồng ở khu vực lân cận đều có thể phát triển tốt ở đây. Do vậy, địa phương có thể sử dụng các loài cây này để phục hồi, phát triển, mở rộng diện tích rừng ngập mặn.

Ở khu vực ven biển tỉnh Thái Bình, thực vật ngập mặn chịu tác động tiêu cực của các điều kiện: thời kỳ khô hạn vào đầu mùa đông; thời tiết lạnh trong những đợt gió mùa cực đới hoạt 
động mạnh; thời tiết nóng trong những tháng mùa hè và tác động của bão và áp thấp nhiệt đới.

Các nhận định nêu trên mới chỉ xét dưới góc độ khí hậu, sinh khí hậu. Đây là một trong những cơ sở khoa học góp phần định hướng phát triển rừng ngập mặn. Để có một định hướng đúng đắn, khoa học hơn cần có những đánh giá thêm dưới góc độ các chuyên ngành khoa học khác.

\section{Lời cảm ơn}

Bài báo được tài trợ từ đề tài VAST.NĐP. 02/15-16 do TS. Lưu Thế Anh chủ nhiệm.

\section{Tài liệu tham khảo}

[1] Ủy ban nhân dân tỉnh Thái Bình, Quyết định số 1894/QĐ-UBND ngày 13/7/2016 về việc "Phê duyệt kế hoạch bảo vệ và phát triển rừng tỉnh Thái Bình giai đoạn 2016-2020". Thái Bình, 2016.

[2] Lâm Công Định, Sinh khí hậu ứng dụng trong lâm nghiệp ở Việt Nam, NXB Khoa học và Kỹ thuật, Hà Nội, 1992.

[3] Đặng Thị Hồng Thủy, Khí tượng Nông nghiệp, NXB Đại học Quốc gia Hà nội, 2003.

[4] Nguyễn Khanh Vân, Nguyễn Thị Hiền, Phan Kế Lộc, Nguyễn Tiến Hiệp, Các biểu đồ sinh khí hậu Việt Nam, NXB Đại học Quốc gia Hà Nội, 2000.

[5] Trần Văn Thụy, Phan Tiến Thành, Đoàn Hoàng Giang, Phạm Minh Dương, Nguyễn Thu Hà, Nguyễn Minh Quốc, Nghiên cứu ảnh hưởng của biến đổi khí hậu đến một số hệ sinh thái ven biển tỉnh Thái Bình và khả năng ứng phó. Tạp chí Khoa học ĐHQGHN: Khoa học Tự nhiên và Công nghệ, Tập 32, Số 1S (2016).

[6] Nguyễn Thị Kim Cúc, Đào Văn Tấn, Nghiên cứu thực vật vùng rừng ngập mặn xã Thụy Trường, huyện Thái Thụy, tỉnh Thái Bình : Trong Phan Nguyên Hồng (chủ biên). Hệ sinh thái rừng ngập mặn ven biển đồng bằng sông Hồng: Đa dạng sinh học, sinh thái học, kinh tế, xã hội - quản lý - giáo dục, NXB Nông nghiệp, Hà Nội (2004) 35.

[7] Đoàn Đình Tam, Một số đặc điểm thực vật vùng rừng ngập mặn tại Đông Long - Tiền Hải - Thái Bình, Tạp chí Khoa học Lâm nghiệp 4 (2013) 3009
[8] Mai Sỹ Tuấn, Phan Hồng Anh, Thảm thực vật vùng rừng ngập mặn thuộc $\mathrm{Khu}$ bảo tồn thiên nhiên đất ngập nước Tiền Hải, Thái Bình: Trong Phan Nguyên Hồng, Nguyễn Thị Kim Cúc, Vũ Thục Hiền: Phục hồi rừng ngập mặn: ứng phó với biến đổi khí hậu hướng tới phát triển bền vững, NXB Nông nghiệp, Hà Nội (2008) 305.

[9] International Union for Conservation of Nature (IUCN), 2010. Red List of Threatened Species (ver. 2010.2). http://www.iucnredlist.org.

[10] Robertson, A.I. and Alongi, D.M., Tropical Mangrove Ecosystems. American Geophysical, 1992.

[11] Chandrasekaran M., Senthilkumar A., Venkatesalu V., Antibacterial and antifungal efficacy of fatty acid methyl esters from the leaves of Sesuvium portulacastrum L.. European Review for Medical and Pharmacological Sciences. 15 (7) (2011) 775-780.

[12] Peng, L. and Xin-men, W., Ecological notes on the mangroves of Fujian, China. In: H.J. Teas (ed.), Biology and Ecology of Mangroves, Boston (1983) 31.

[13] Phan Nguyên Hồng, Sinh thái thảm thực vật rừng ngập mặn Việt Nam, Luận án Tiến sỹ khoa học sinh học, chuyên ngành Sinh thái học, 1991.

[14] Terrados, J., Thampanya, U., Srichai, N., Kheowvongstri, P., Geertz-Hansen, O., Boromthanarath, S., Panapitukkul, N. and Duarte, C.M., The effect of increased sediment accretion on the survival and growth of Rhizophora apiculata seedlings. Estuarine, Coastal and Shelf Science 45 (1997) 697.

[15] Tomlinson P. B., The botany of mangroves. Cambridge University Press, Cambridge. (1986) 413.

[16] Ellison J., 'How South Pacific mangroves may respond to predicted climate change and sea level rise', in Gillespie, A. and Burns, W. (eds), Climate Change in the South Pacific: Impacts and Responses in Australia, NewZealand, and Small Islands States. Kluwer Academic Publishers, Dordrecht, Netherlands, (Chapter15) (2000) 289.

[17] Phan Nguyên Hồng, Rừng ngập mặn Việt Nam, Nxb Nông nghiệp Hà Nội. 1999.

[18] Clough B.F., Andrews T.J. and Cowan I.R., Primary Productivity of Mangroves. Australian Institute of Marine Science, Townsville, and Australian National University Press, Canberra, Australia, 1982.

[19] Ball M., Ecophysiology of mangroves. Trees 2 (1988) 129. 
[20] Phan Nguyen Hong, Hoang Thi San, Mangrove of Vietnam. IUCN. Bangkok. Thailand, 1993.

[21] Millan, C., Environmental factors effecting seedling establishment of the black mangrove on the central Texas coast. Ecology 52 (1971) 927.

[22] Andrews T.J.,Clough B.F., Muller G.J., Photosynthetic gas exchange properties and carbon isotope ratios of some mangroves in North Queens-land. In: Teas, H.J.(Ed.), Physiology and Management of Mangroves, Tasks for Vegetation Science, vol. 9. Dr. W. Junk, The Hague, (1984) 15.

[23] Phan Nguyên Hồng, Đào Văn Tấn, Vũ Thục Hiền, Trần Văn Thụy, Thành phần và đặc điểm của thảm thực vật vùng rừng ngập mặn huyện Giao Thủy: Trong Phan Nguyến Hồng (chủ biên). Hệ sinh thái rừng ngập mặn ven biển đồng bằng sông Hồng: Đa dạng sinh học, sinh thái học, kinh tế, - xã hội - quản lý - giáo dục, NXB Nông nghiệp, Hà Nội, (2004) 51.

[24] Lê Xuân Tấn, Phan Nguyên Hồng, Phan Thị Anh Đào, Vũ Thục Hiền, Quản Thị Quỳnh Dao, Phan Hồng Anh, Vũ Đình Thái, Trần Minh
Phượng, Phan Thị Minh Nguyệt, Hệ sinh thái rừng ngập mặn huyện Giao Thủy, tỉnh Nam Định và một số vấn đề quản lý. Trong Phan Nguyên Hồng, Nguyễn Thị Kim Cúc, Vũ Thục Hiền: Phục hồi rừng ngập mặn: ứng phó với biến đổi khí hậu hướng tới phát triển bền vững, $\mathrm{NXB}$ Nông nghiệp, Hà Nội (2008) 151.

[25] Hoàng Công Đãng, Đỗ Thanh Vân, Một số kết quả nghiên cứu trồng Dừa nước (Nipa fruticans Wurmb) ở Quảng Ninh. Trong Phan Nguyên Hồng, Nguyễn Thị Kim Cúc, Vũ Thục Hiền : Phục hồi rừng ngập mặn: ứng phó với biến đổi khí hậu hướng tới phát triển bền vững. NXB Nông nghiệp, Hà Nội (2008) 221.

[26] Kuei-Chu Fan, Mangrove in Taiwan: current status and restoration projects. Bois et forêts des tropiques, N273 (3) (2002) 43.

[27] Hai Ren, Hongfang Lu, Weijun Shen, Charlie Huang, Qinfeng Guo, Zhi'an Li, Shuguang Jian, Sonneratia apetala Buch.Ham in the mangrove ecosystems of China: An invasive species or restoration species?. Ecological Engineering 35 (2009) 1243.

\title{
Bioclimate and Mangrove Development in Thai Binh Coastal Zone
}

\author{
Tran Thi Thuy Van, Luu The Anh, Hoang Luu Thu Thuy, Le Ba Bien \\ Institute of Geography, Vietnam Academy of Science and Technology, \\ 18 Hoang Quoc Viet, Hanoi, Vietnam
}

\begin{abstract}
In spite of occupying a small area, mangrove has a great sigfinicance in terms of ecological and environmental protection in the two coastal districts of Thai Binh province. Mangrove development in this area is proposed on the regional analytical bases of mangrove current status, climatic and bioclimatic conditions with the ecological thresholds. Thai Binh littoral zone has 14 major mangrove plants, belonging to the following communities: natural forest, planted forest, aquaculture related plants, pioneer plants in newly formed tidal flats. In general, the regional bioclimatic conditions are suitable for mangrove forestation with 14 local present major species and 3 others newly introduced in adjacencies such as: Nipa fruticans, Lumnitzera littorea and Sonneratia apetala. The bioclimatic restraints for mangrove development in this area includes: dry in the early winter, cold weather in polar monsoon activity; hot weather in summer, storms and tropical depressions.
\end{abstract}

Keywords: Bioclimate, mangrove, Thai Binh. 